\title{
The Selection and Ues of Image Historical Materials in History Textbook: Take the Example of The Picture of Confucius Teaching
}

\section{Lijuan Zhang}

\begin{abstract}
The image historical materials have the vital historical and teaching value. This paper took the example of The Picture of Confucius Teaching, analyzed a teaching practice about the selection and use of image historical materials in history textbooks. It is agreed that before the invention of photographic technic, most of the image historical materials are the author's imaginations. The students' interpretations of The Picture of Confucius Teaching were not the simple picture interpretations, but rather were their own previous experience reflection. When textbook editors and teachers selected the image historical materials, they should understand what the images want to transfer, studied and estimated seriously what the images reflected. If the images distorted, misrepresented the original history, we must select and use it carefully.
\end{abstract}

Key words: the Image Historical Materials, the Selection and Use of Imges, the Picture of Confucius Teaching. 


\section{Introduction}

Image historical materials can be called audio-visual historical materials, which included maps, pictures, paintings, photographs, statue, relics, film and television etc. (Shen Minhua, 2005, 109).From the source, image historical materials can also be divided into primary images and reproductive images. Primary images enjoy a higher degree of authenticity. The reproductive images were created by authors' imagination and experience, due to the subjective and objective reasons, there existed a gap between the images and reality.

\section{The Value of Image Historical Materials}

Images have the vital historical and teaching value. Images themselves also are history, which recorded history from the different angles. Images can be used as historical evidence (Peter Burke, 2009, 1), supplement history (Chen Zhongdan, 2013, 65), makes the history more clearly and vividly (Qian Huizhen, 2011, 177-180). Images have the vital historical values. The unearthed Qin Terracotta Warriors and Horses in Xi'an proved what Sima Qian said in Historical Records was true. For a very long time, ancient Sichuan was considered as wild places, but the historical relics of Sanxingdui and Jinsha proved that ancient Sichuan enjoyed a high level of civilization, and also was one of the birthplaces of Chinese civilization. There are many beautiful words described olive green porcelain, such as their color looked like green lake, glittering and translucent moist as a jade, only the Royal can use it. People are very curious about what the mysterious porcelain look like. Until the Xi'an Famen Temple cultural relics unearthed, can people believed that the olive green porcelain really existed, the relics supplement with the words, made the history more clearly and vividly.

Images can also be served as political tools, such as the famous photos The Vulture and the Little Girl (also called Hungry Sudan), and The Running Children in Vietnam War. Both of the two pictures won the Pulitzer News Prize. In 1993, Sudan broke out a war, many people died of famine. A bony girl was so hungry, she will die down. behind her a also hungry vulture was waiting for the girl to die and to eat her. The photo was published in The New York Times in March of 1993, and sparked a wide reaction. The Running Children in Vietnam War was chosen as the World Press Photo of the Year for 1972. It communicated the horrors of the Vietnam War in a way words could never describe, people took this photo as a turning point of public attitudes (Kiku Adatto, 2015, 101). The publication of the photo urged the United States to end one of the most divisive wars in American history. People evaluated the photographer Huynh Cong Ut helping to end the Vietnam War earlier. 
Images also have vital teaching value. Using images can attract students' attention, improve learning interesting, make the boring and difficult content become more vividly(Li Chunxia,2011, 6-9).Teachers can use images to cultivate students' abilities of observation, imagination, understanding and appreciation of the beauty (Huang Muhang, 2001, 27). Teacher also can use images to cultivate students' consciousness of scientific historical inquiry, make students' emotional resonance (ZhangJian, 2009, 2-19).

\section{A Teaching Practice about The use of Image Historical Materials}

Teaching content: A Hundred Schools of Thought Contend and the Formation of Confucianism

Teaching method: discussion in-group

Teaching task: which thoughts and historical contributions of Confucius The Picture of Confucius Teaching reflected?

Figure 1

The Picture of Confucius Teaching

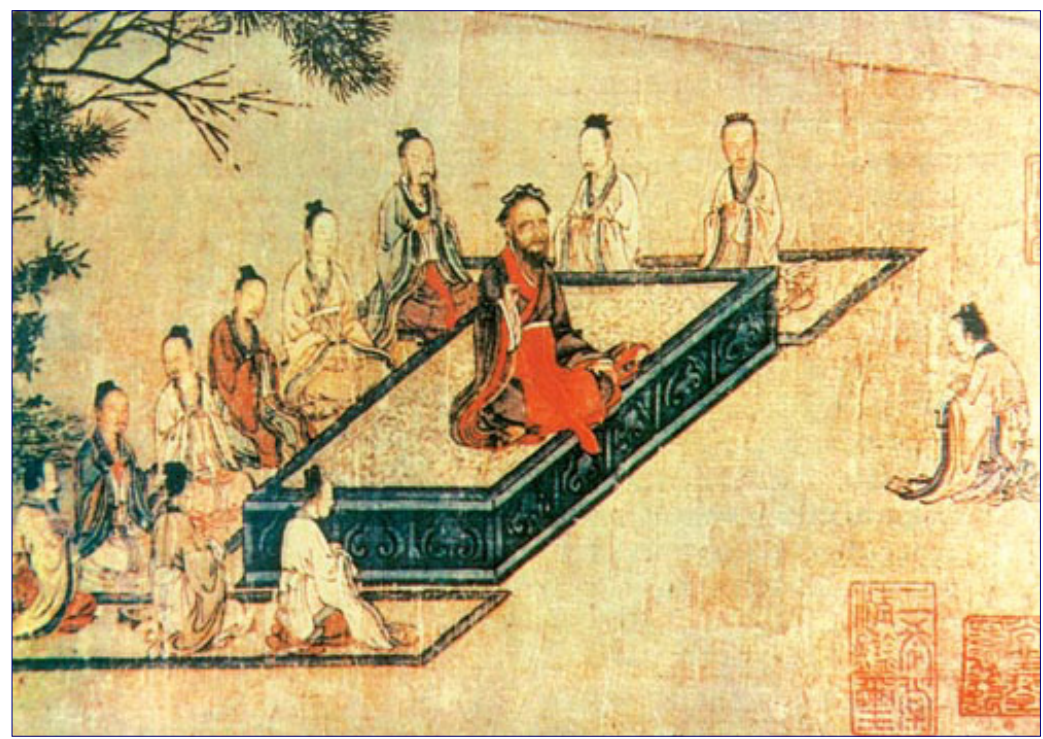


There is a picture in a text of $A$ Hundred Schools of Thought Contend and the Formation of Confucianism in a upper secondary school. When a teacher named Shen Weihui taught the lesson, he didn't know how to teach students this picture. So at first he looked up the information from many books, Internet, libraries, but failed. Finally he consulted a professor from history department of Nanjing Normal University. Professor Zhang told him this picture's author is a painter of Ming dynasty, but no caption. He advised teacher Shen let the students find the answers by themselves. Inspired by what professor Zhang said, teacher Shen gave the pupils a task: which thoughts and historical contributions of Confucius The Picture of Confucius Teaching reflected? Please discussed this question and submit the answers in-group. After a heated discussion, students submitted their answers, as follows:

Table 1

Students' Answers (positive view)

\begin{tabular}{|c|l|}
\hline Number & Students' Answers \\
\hline 1 & Students respected teacher \\
\hline 2 & Confucius' teaching focused on communication and discussion \\
\hline 3 & The relationship between teacher and students was harmonious \\
\hline 4 & Teaching out doors \\
\hline 5 & Provided education for all social classes \\
\hline 6 & Teaching in accordance with students' aptitude \\
\hline 7 & Look up to men and down on women, women had no right to be educated \\
\hline 8 & The happy learning of quality education \\
\hline 9 & No classroom, this was a private school \\
\hline
\end{tabular}

Teacher Shen reported students' answers to professor Zhang, after revised by professor Zhang, teacher Shen made such a conclusion: The Picture of Confucius Teaching reflected Confucius' educational thoughts and historical contributions, such as Confucius founded a private school, teaching learners without division of classes, outdoor teaching, ritual culture, the harmonious teachers and students relations (Shen Weihui, 2007, pp. 38). This teaching practice once served as a masterpiece of exploiting image historical materials, many secondary school history teachers learned from it, and many experts praised it (Chen Yadong, 2007, pp. 39-40).

But there were some other secondary school teachers did the same experiment in theri own classroom (Liuqiang, 2010, 78). Some of their students' answers were very different with others, as follows: 
Table 2

Students' Answers (negative view)

\begin{tabular}{|c|l|}
\hline Number & Students' Answers \\
\hline 1 & The relationship between teacher and students was unequal \\
\hline 2 & The learning atmosphere was very depressing \\
\hline 3 & Confucius expounded his idea mechanically \\
\hline
\end{tabular}

They told their teachers that Confucius sat in the middle of the students, his position was higher than others, the disciples sitting around him. It seemed that the relationship between teacher and pupils was unequal. There was a student absent-mindedness in class, his attention was not centralized. His face toward the other students instead of Confucius. The learning atmosphere was very depressing, no discussion, no debate. Confucius only was a boring preacher.

\section{The Misapplication of Image Historical Materials and Application Notice}

Why there existed such huge difference? There are three questions we should consider: Does the picture really reflected Confucius' thoughts? Were the students' interpretations the reflection of their own previous experience or purely the illustration of the picture? If picture distorted the real history, can and how we use it in teaching?

It is well known that before the invention of photographic technic, most of the image historical materials were the author's imagination. According to their own experience, educational background and the previous documents, the authors produced such images. Absolutely, these were not the accurate images of the historical reality.

Li-Xue ideology was very prevalent in Ming dynasty, The imperial examinations focused on learning by rote. The scene of relationship between teacher and pupils was unequal and the learning atmosphere was depressing described in The Picture of Confucius Teaching more tally with the actual situation of Ming dynasty. The painter gave Confucius' teaching the educational characteristic of Ming dynasty.

There existed some distorted facts in the details of The Picture of Confucius Teaching, which reflected the actual education of Ming dynasty, but not Confucius' educational thoughts. These images were some kind of understanding of history, which including authors' imagination, absolutely not the actual historical original features. The students' interpretations of The Picture of Confucius Teaching were not the simple picture interpretations, but rather were their own previous experience reflection. Although this imagination more or less based on the historical records, however, in general, these imaginations cannot be used as historical data directly. And the picture of Confucius 
teaching is no exception. When we research Confucius thoughts and achievement, the picture of Confucius teaching only can be served as secondary source.

Similarly, when a teacher taught students the urban economy of the northern Song dynasty, he used a famous Chinese painting Qingming Festival in his teaching (Ji Lianhai, 2009, pp. 22-28). But there are many versions of this painting, the Qing version of this painting is very different with northern Song version, which reflected the Qing dynasty's urban economy, rather than the Song dynasty, this teacher use Qing versions to teach students urban economy of northern Song dynasty (Zhao Chenyan et al., 2009, 9). Obviously, This was another typical misapplication of image historical materials.

Views come from historical material, and history comes from evidence, which are the unique characteristic of history discipline (Xu Jinchao, 2008, 45). The cultivation of historical thinking abilities, the acquired of historical experience and the formation of students' values depend on the reliable historical fact. The reliable historical fact is the essential characteristics of history teaching. Teacher Shen let students inquired the picture of Confucius teaching, students inquired the information about Confucius' thoughts, we can not say there was not the consciousness of historical evidence, but during the teaching and studying process, teacher Shen took the paintings of an unknown painter of Ming dynasty as a reliable historical material to make a study of Confucius' thoughts. The consciousness of historical evidence was more or less vulgarized, and also lack of the sense of historical identification.

It's agreed that although there existed some distorted facts in the details of the images, if the basic historical fact of the images contained is true, we can use them in teaching. But if we want to make rigorous history research, we should consider it carefully. For example, we know in the image of many soldiers with an American flag was posed in the picture of the famous Battle of Iwo Jima. But the fact U.S. military occupied Iwo Jima was true, so, when we used this kind of pictures to teach students U.S. military occupied Iwo Jima, we needn't to investigate whether the scene was posed or filmed immediately. On the contrary, due to the influence of political reason, ideology, some pictures totally distorted the fact. We should use them discriminately. For example, some people changed the figure of Zhude joined forces with Mao Zedong into linbiao joined forces with Mao Zedong in the oil painting of jinggangshan stationed during the Cultural Revolution. When we are teaching students Jingganshan stationed, we can't use it, but when we are teaching students the Cultural Revolution, we can use this picture to illustrate how politics affected art field.

\section{Conclusion}

We can make full use of image historical materials in history teaching, but when we choose the images, we should pay much attention to the authenticity of the selected images. The Picture of Confucius Teaching reflected the actual educational situation of 
the Ming dynasty, rather than Confucius education thought. So, it's inappropriate for editors and teachers to select The Picture of Confucius Teaching to illustrate Confucius thoughts.

What pictures want, is not to be interpreted, decoded, worshipped, smashed, exposed, or demystified by their beholders, or to enthrall their beholders... What pictures want in the last instance, is simply to be asked what they want (Mitchell, 2005, 48). When history teachers use image historical materials to teach students, they should pay attention to the guidance for the students' reading images strategies and the cultivation of students' reading images abilities. When textbook editors selected the image historical materials into history textbooks, they must understand the content of images want to transfer, studied and estimated seriously the truth of content of images reflected. There are the following principles we should focused on, that is, scientific principle, interesting principle, representative principle, pertinence principle, moderate principle, etc. The scientific nature of the images are the most basic principle of the selection of image historical materials. We must consider whether the images conveyed the true, original historical information. At the same time, on the premise of the ensuring the scientific images, we should select the interesting, audio-visual, figurative and vivid images to fully arouse the students' enthusiasm for study, to enlighten students' thought, to enhance interest and vividness in history teaching. Representative principle means when textbook authors select images, facing so many images, they should choose those which can make sure students master the essence of historical knowledge in the shortest possible time. For example, when there exist several images which can show the same historical content, the history textbook editors should select the most persuasive one. Pertinence principle means when we select images, we should consider the important and difficult points of textbook. As for the important content, we can add some pictures to deepen the students'memory. For the difficult points which can not easily express with words, we can use some pictures to provide either supplementary or explanatory information. Moderate principle references to the number of the images in textbooks is not the more the better, too many images maybe a reversal of the order of host and guest, will distract students' attention. Practice has proved that in general, the proportion of the images and text should be controlled between $1: 1$ and $1: 2$.

In conclusion, the selection and use of image historical materials is a promising research field. Paying great attention to the images selection, contrast the pros and cons of different images, exploring the implication of the images, making a study of images teaching, are some solid research work need to be done.

\section{Acknowledgements}

This paper is dedicated to the following projects: The research of the value orientation in secondary school history textbooks (15YJC880131), funded by Ministry of Education 
of the People's Republic of China; The research of the exploitation and utilization in secondary school history textbooks resources (15ZD007), funded by Sichuan Normal University. IGA_PdF_2015_022 „Popis základních fenoménů vztahu edukace a myšlení $v$ kontextu konstruktivistického vzdèlávání učitelů a žákü"

\section{References}

Shen Minhua (2005). The application of image historical materials in history teaching. Issue of The History Teaching, 5, 109.

Peter Burke (2009). Eyewitnessing: the uses of images as historical evidence, Beijing: Peking University Press.

Chen Zhongdan (2013). On the value of images as historical evidence. History teaching, 1, 65.

Qian Huizhan, (2011). The use of historical images in history teaching. Research of modern basic education, 9, 177-180.

Kiku Adatto, (2015). Picture Perfect: Life in the Age of Photo Op. Beijing: Peking University Press.

Li Chunxia, (2011). The exploiting and utilization of historical pictures. Nanjing Normal University Masters Thesis.

Huang Muhang, (2001). The theory and practice about the picture design of the secondary school history textbooks. History teaching, 9, 25-30.

Zhang Jian, (2009). The meaning and utilization of image historical materials in history teaching. East China Normal University Masters Thesis.

Shen Weihui, (2007).Students taught me interpret the picture of Confucius teaching. History Teaching Reference of Secondary School. 12, 37-38.

Chen Yadong, (2007). From the Students taught me interpret the picture of Confucius teaching look the utilization and development of historical curriculum resource. History Teaching Reference of Secondary School, 12, 39-40.

Liuqiang, (2010). Be tolerant of students' different oppinions. The research of educational science, $4,78$.

Ji Lianhai, (2009). From Qingming Festival to see the urban economy of northern Song dynasty. History teaching, 12. 22-28.

Zhao Chenyan, etc. (2009). Wonderful teaching, regretful mistake: the discussion about the teaching practice from Qingming Festival to see the urban economy of northern Song dynasty. History teaching, 11, 5-11.

$\mathrm{Xu}$ Jinchao, (2008). Worrying about historical inquiry learning: the deviation of the consciousness of history comes from evidence. History Teaching Reference of Secondary School. 4, 45-46.

Mitchell, W. J. T., (2005). What do Pictures Want? The lives and loves of images. Chicago and London: The University of Chicago Press.

\section{Contact:}

Lijuan Zhang

Sichuan Normal University,Chengdu,China,610066

Faculty of Education, Palacky University, Olomouc, CZ, 77140

E-mail: li.zhang01@upol.cz 